\title{
Biosulphidogenesis: Isolation and characterization of Thermodesulfobacterium commune sp. nov. Isolated from hot water springs of Thane, Maharashtra.
}

\author{
${ }^{1}$ Sonali Z. Patil, ${ }^{2}$ Anju R. Unnithan, ${ }^{3}$ Geetha Unnikrishnan* \\ ${ }^{1,2}$ Department of Biotechnology, Birla College of Arts, Science and Commerce, Kalyan, Maharashtra, INDIA \\ ${ }^{3 * D e p a r t m e n t ~ o f ~ Z o o l o g y, ~ B i r l a ~ C o l l e g e ~ o f ~ A r t s, ~ S c i e n c e ~ a n d ~ C o m m e r c e, ~ K a l y a n, ~ M a h a r a s h t r a, ~ I N D I A ~}$
}

\begin{abstract}
Biosulphidogenesis was examined in thermal waters, sediments and decomposing bacterial mats associated with Vajreshwari \& Ganeshpuri hot springs, Thane. In vitro studies demonstrated biological sulphide production from sulphate at temperatures higher than $50^{\circ} \mathrm{C}$ but less than $85^{\circ} \mathrm{C}$, correlated with the presence of a unique sulphate-reducing bacterium (TSRP-Thermophilic Sulphate Reducing Prokaryote). It showed complete reduction of sulpahte in 20 hrs with negligible production of sulphide. This new species proliferated at temperatures above $50^{\circ} \mathrm{C}$ but below $85^{\circ} \mathrm{C}$, and had an optimum growth temperature of $60^{\circ} \mathrm{C}$ in anaerobic condition (The anaerobic condition was maintained by overlaying the media with Paraffin oil). The organism was a small gram-negative, straight rod, utilized lactate as electron donors and sulphate as electron acceptors for growth and forming sulphide, indicating presence of dissimilatory sulphate reduction mechanism. Other unusual biochemical features of this extreme thermophile includes tolerance to $1.5 \% \mathrm{NaCl}$, lacked catalase activity and non motile. Strain TSRP is described as the type strain of the species Thermodesulfobacterium commune identified by 16s $r$ RNA sequence analysis and phylogenetic relationship was found in between different OTUS which were determined by CLUSTALW.

The assessment of the effluents collected from 3 industries viz., Textile, Battery, Paper \& pulp; within the city zone of Thane showed high concentration of sulphate. These effluents were subjected to sulphidogenesis by T. commune \& there was a complete reduction of sulpahte in 25,24,22 hrs. respectively with negligible production of sulphide.
\end{abstract}

The study showed that T. commune can be used for treating effluent containing sulphate, thus important for bioremediation process with high efficiency of sulfate reduction rate and negligible production of sulphide.

Keywords: Biosulphidogenesis, TSRP, Dissimilatory Sulphate reduction pathway, 16s rRNA

\section{Introduction}

Life on the earth is dependent on balanced recycling of various elements like nitrogen, carbon, sulfur etc. Out of which sulphur is present in its most reduced form in biological material. During decomposition of this material, sulfide is oxidized to sulphate under aerobic conditions while during anaerobic condition sulphide is liberated as hydrogen sulfide (Christian Jeanthon, et.al.,2002). Another important source of hydrogen sulphide is dissimilatory sulphate reduction by anaerobic microorganism which uses sulphate as electron acceptor for oxidation of organic compound. Sulphate reducers play an important role in balancing the sulphur cycle.

Human activities have a major effect on the global sulfur cycle. The burning of coal, natural gas, and other fossil fuels has greatly increased the amount of $S$ in the atmosphere and ocean and depleted the sedimentary rock sink. Sulphates or sulphuric acid products are also used in the manufacture of numerous chemicals, dyes, glass, paper, soaps, textiles, fungicides, insecticides, astringents and emetics. They are also used in the mining, pulping, metal and plating industries, in sewage treatment and in leather processing. These effluent containing sulphate are discharged into the aquatic body. The aesthetic objective for sulphate in drinking water is $\leq 500 \mathrm{mg} / \mathrm{L}$, based on taste considerations. Because of the possibility of adverse physiological effects at higher concentrations, it is also recommended that health authorities be notified of sources of drinking water that contain sulphate concentrations in excess of $500 \mathrm{mg} / \mathrm{L}$.

Many bacteria reduce sulpahte in large amount to produce energy and to expel sulfide as waste. These bacteria are known to be sulphate reducing bacteria (Anna H. Kaksonen,et.al.2006). Thermophilic bacteria from the hot water spring are adapted to the environment containing high amount of sulphate. Thus can serve as an important tool for biosulphidogenesis. The aim of the study was to isolate, characterize and identify thermophilic sulfate reducing prokaryote (TSRP) from Vajreshwari and Ganeshpuri hot springs, Thane, Maharashtra. 


\section{Materials and Methods}

Sampling

Water samples were collected from seven different hot springs (from Vajreshwari and Ganeshpuri, Thane) Mumbai. Various parameters were noted down like temperature, $\mathrm{pH}$, etc. the samples were taken into clean polyethylene container with lid. Water sample used for inorganic analyses was immediately fixed with zinc acetate solution as described in APHA (Patil S. Z. et. al., 2014).

Media and growth Conditions :

The enrichment and isolation of the strains were carried out using Medium 77 (g/ Lit.: K2HP04, 0.5; $\mathrm{NH} 4 \mathrm{C} 1,1.0 ; \mathrm{CaC} 1,2 \mathrm{H} 20,0.1 ; \mathrm{MgS} 04.7 \mathrm{H}, 0,0.1$; sodium lactate, 5 ; yeast extract, $1.0 ; \mathrm{FeS} 0, .7 \mathrm{~Hz} 0,5$; sodium thioglycolate, 1.0; and ascorbic acid, 1.0). The anaerobic condition was maintained by overlaying the media with sterile paraffin oil. The pure colonies of the strains were isolated from the media after incubation at $65^{\circ} \mathrm{C}$. The stock culture were maintained in Medium 77 and preserved at $4^{\circ} \mathrm{C}$ for further use.

Characterization of the isolates :

I) Morphological Studies and Biochemical Studies :

The thermophilic isolate was identified by presumptive conventional, physiological and biochemical tests. These tests were (according to Bergey's manual) Gram reaction, catalase production, hydrolysis of protein, starch and lipid, and acid production from sugar. The species was reconfirmed in an automated Biomerieux Vitek 2 System (At Nucleus Diagnostic Centre, Kalyan).

II) Optimization of Growth Conditions:

Determination of the Optimum $\mathrm{pH}$, Temperature and Sodium Chloride Concentration:

The optimum $\mathrm{pH}$ for growth was determined using phosphate buffer, universal buffer, and Tris - HCI buffer to obtain different $\mathrm{pH}$ values in the range of 4.0 to $9.0 \mathrm{pH}$ and was confirmed using $\mathrm{pH}$ meter. For finding out optimum temperature, cultures were streaked onto agar plates and incubated at a range of temperatures from 50$80^{\circ} \mathrm{C}$. The plates were observed daily up to 5 days.

For $\mathrm{NaCl}$ tolerance level, $100 \mathrm{ml}$ of isolation medium prepared in a phosphate buffer at final concentration of $50 \mathrm{mM}$ and at a final salt $(\mathrm{NaCl})$ concentration of $0.5 \%, 1.5 \%, 3.0 \%, 4.5 \%, 6.0 \%$ and $7.5 \%, .1$ $\mathrm{ml}$ of culture was added and the flask was incubated at $41^{\circ} \mathrm{C}$ in an orbital shaker running at $200 \mathrm{rpm}$. The growth was determined at $3 \mathrm{~h}$ intervals by measuring the O.D at $550 \mathrm{~nm}$. (For all the experiments anaerobic conditions were maintained as described above).

III) Sample Collection of effluent from industries:

The effluents having high concentration of sulphate from 3 industries viz., Textile, Battery, Paper \& pulp; within the city zone of Thane were collected into polyethelene bottles $(500 \mathrm{ml})$. The sample was first analysed to find out the concentration of sulphate and sulphide (Turbidometric method, and Iodometric Method respectively, APHA). Effluents were then exposed to TSRP for reduction of sulphate to sulphide.

IV) Biosulphidogenesis:

Sulphate reduction rate (SRR) and sulphide production rate (SPR) for standard sulpahte and for effluent were determined by method described in APHA. The rates were found out in the interval of $2 \mathrm{hrs}$. till $24 \mathrm{hrs}$. (All the experiments were done in triplets).

V) Strain identification by 16 s rRNA Analysis:

The isolated colony was sequenced for its conserved sequences and analysed for partial 16s rRNA (Sequencing was done at geneOmbio, Pune, Maharashtra).

The predicted 16S rRNA sequences were compared using the program BLAST (ftp://ftp.ncbi.nih.gov/BLAST/executables/LATEST/).

VI) Phylogenetic and Evolutionary Analysis :

Partial 16S rRNA gene sequences representing the 5 most prevalent OTUs (Operational Taxonomic Units) from thermophilic environment (NCBI database) were aligned using CLUSTALW. Phylogenetic and molecular evolutionary analyses were performed using software cladogram. 


\section{Results and Discussion}

The strain isolated from the hot water spring Si was anaerobic, extremely thermophilic bacteria with optimum temperature of $60, \mathrm{pH} 5.5$ and $\mathrm{NaCl}$ tolerance level upto $1.5 \%$. The biochemical properties are shown in Table 1 and 2.

The isolated strain showed complete reduction of standard sulphate in $20 \mathrm{hr}$ with negligible production of sulphide. And assessment of effluent from the industry showed the rate of reduction of complete sulphate in $25,24,22 \mathrm{hrs}$. respectively with negligible production of sulphide, refer table 3.

Table 1: Biochemical Properties of TSRP (According to Bergey's manual)

\begin{tabular}{|l|l|}
\hline \multicolumn{1}{|c|}{ Characteristics } & Strain si \\
\hline Gram Nature & Gram Negative \\
\hline Shape & Curved \\
\hline Motility & Non motile \\
\hline Temperature ${ }^{\circ} \mathrm{C}-$ Optimum & 60 \\
\hline pH - Optimum & 5.5 \\
\hline NaCl \% - Optimum & 1.5 \\
\hline Oxidase & - \\
\hline Catalase & - \\
\hline Casein & - \\
\hline Starch & + \\
\hline D-Glucose & + \\
\hline D-Fructose & - \\
\hline Maltose & - \\
\hline Mannose & - \\
\hline Trehalose & + \\
\hline Sucrose & - \\
\hline Mannitol & + \\
\hline Melibiose & - \\
\hline Lactose & + \\
\hline Xylose & - \\
\hline Galactose & + \\
\hline Nitrate & + \\
\hline Citrate & + \\
\hline
\end{tabular}

Key : Growth : + ; No Growth :-

Table 2: Biochemical Tests ( By Biomerieux Vitek 2 System)

\begin{tabular}{|l|l|l|l|l|l|l|l|l|l|l|l|l|l|l|l|l|l|}
\hline \multicolumn{1}{|l|}{ Biochemical Details } \\
\hline 2 & APPA & - & 3 & ADO & - & 4 & PyrA & - & 5 & IARL & - & 7 & d CEL & - & 9 & BGAL & + \\
\hline 10 & H2S & + & 11 & BNAG & - & 12 & AGLTp & - & 13 & d GLU & + & 14 & GGT & - & 15 & OFF & + \\
\hline 17 & BGLU & + & 18 & dMAL & - & 19 & dMAN & + & 20 & dMNE & - & 21 & BXYL & - & 22 & BAlap & - \\
\hline 23 & ProA & - & 26 & LIP & - & 27 & PLE & - & 29 & TyrA & + & 31 & URE & - & 32 & dSOR & - \\
\hline 33 & SAC & + & 34 & d TAG & - & 35 & d TRE & + & 36 & CIT & + & 37 & MNT & - & 39 & 5 KG & + \\
\hline 40 & ILATk & + & 41 & AGLU & - & 42 & SUCT & + & 43 & NAGA & - & 44 & AGAL & + & 45 & PHOS & - \\
\hline 46 & GlyA & - & 47 & ODC & + & 48 & LDC & + & 53 & IHISa & - & 56 & CMT & + & 57 & BGUR & - \\
\hline 58 & $0129 R$ & - & 59 & GGAA & - & 61 & IMLTa & + & 62 & ELLM & - & 64 & ILATa & + & & & \\
\hline
\end{tabular}

Table 3: Initial and final concentration of sulphate and sulphide before and after the treatment of effluent collected from 3 industries by TSRP strain Si.

\begin{tabular}{|l|c|c|c|c|c|c|c|}
\hline \multicolumn{1}{|c|}{ Industry / Standard } & \multicolumn{3}{|c|}{$\begin{array}{c}\text { Sulphate concentration } \\
(\mathrm{mg} / \mathrm{L})\end{array}$} & $\begin{array}{c}\text { Sulphate } \\
\text { Reduction } \\
\text { rate (\%) }\end{array}$ & $\begin{array}{c}\text { Sulphide } \\
\text { concentration } \\
(\mathrm{mg} / \mathrm{L})\end{array}$ & $\begin{array}{c}\text { Increase in } \\
\text { Sulphide } \\
\text { Production rate } \\
(\%)\end{array}$ \\
\hline & Initial & Final & $\begin{array}{c}\text { Reduction Time } \\
(\text { hrs. })\end{array}$ & & Initial & Final & \\
\hline Standard Sulphate & 500 & 0 & 20 & 100 & -- & 0.5 & 0.5 \\
\hline $\begin{array}{l}\text { Colour and dye } \\
\text { Industry }\end{array}$ & 689 & 0 & 25 & 100 & 15 & 16.1 & 1.1 \\
\hline Paper and Pulp & 789 & 0 & 24 & 100 & 20 & 20.8 & \\
\hline Chemical & 869 & 0 & 22 & 100 & 59 & 60 & 0.8 \\
\hline
\end{tabular}


16s rRNA Analysis:

The sequence of conserved sites by partial sequence analysis gave the following sequences.

$>48816 \mathrm{~S} 1$

ACGACGGGTAGCCGGCCTGAGAGGGTGGTCGGCCACGCGGGCACTGAGACACGGGCCCGACTCCT ACGGGAGGCAGCAGGGGGGAATCTTGGGCAATGGGCGAAAGCCTGACCCAGCGACGCCGCGTGG GGGAAGAAGGCCTTCGGGTCGTAAACCCCTGTTCTGGAGGAAGAACCCAGGGTAGGTGAATAACC TATCCTGGCTGACGGTACTCCAGGAGAAAGCCACGGCTAACTGCGTGCCAGCAGCCGCGGTAATA CGCAGGTGGCGAGCGTTGCCCGTAAAGGGTGCGTAGGCGGCCGGACAAGTCATAGGTTAAAGCCC GGAGCTCAACTCCGGAAAGGCCTATGATACTGTCTGGCTTGAGGGCCGGAGAGGCTGGCGGAATT CCCGGTGTAGGGGTGAAATCCGTAGATATCGGGAGGAACACCGGTGGGGAAGCCGGCCAGCTGG ACGGTTCCTGACGCTGAGGCACGAAAGCGTGGGGA

The sequence were aligned with the existing database and it was found that the srtain isolated was of Thermodesulfobacterium commune. The data has been deposited in Genbank with accession number KJ868727. The phylogenetic relationship between thermophilic OTUS showed the following table of similarity index,Table 4.

Table 4 The Score Table : Percent Similarity Index (As per Sequence Similarity)

\begin{tabular}{|c|l|c|c|c|c|c|}
\hline SeqA & Name & Length & SeqB & Name & Length & Score \\
\hline 1 & Thermodesulfobacterium & 488 & 2 & gi $|143692855|$ gb $\mid$ EF426770.1| & 409 & 44.5 \\
\hline 1 & Thermodesulfobacterium & 488 & 3 & gi $|44735| \mathrm{emb} \mid$ X00084.1| & 292 & 42.47 \\
\hline 1 & Thermodesulfobacterium & 488 & 4 & gi $|440576572| \mathrm{emb} \mid$ HF558369.1| & 1529 & 77.66 \\
\hline 1 & Thermodesulfobacterium & 488 & 5 & gi $|35210323| \mathrm{dbj} \mid$ AB089844.1| & 1500 & 74.59 \\
\hline 1 & Thermodesulfobacterium & 488 & 6 & gi $|219857149| \mathrm{ref} \mid$ NR_024777.1| & 1506 & 80.33 \\
\hline
\end{tabular}

KEY :

Seq 1 Thermodesulfobacterium commune

Seq 2 Geobacillus sp. DDSO21

Seq 3 Methanococcus vanniellii

Seq 4 Thermus thermophilus

Seq 5 Sulfobacillus thermosulfidooxidans

Seq 6 Thermanaeromonas toyohensis

Phylogram :
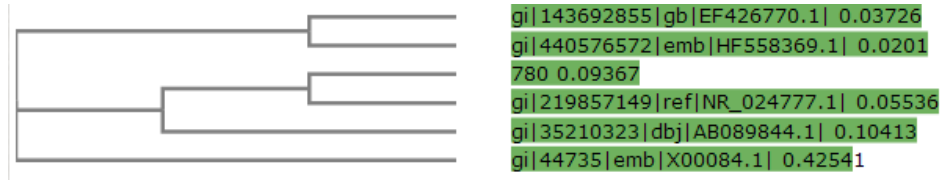

IV. Discussion

The present study intended to identify the disimilatory sulphate reduction in thermophilic bacteria. Strain Si showed 100\% reduction of sulphate $20 \mathrm{hrs}$. The analysis of the effluent collected from various industries showed sulphate level above the permissible limit $(500 \mathrm{ppm})$. These effluents were subjected for sulphidogenesis by TSRP strain $\mathrm{Si}$, and $100 \%$ reduction rate was found in $25,24,22 \mathrm{hrs}$. with negligible production of sulphide. It takes more time for the reduction of sulphate in the effluent sample, may be because of presence of other elements like $\mathrm{H} 2 \mathrm{~S}, \mathrm{Cd}, \mathrm{Ni}, \mathrm{Cu}, \mathrm{Cd}, \mathrm{Cr}, \mathrm{Pb}$ that slow downs the rate of sulphate reduction (Murhekar Gopalkrushna Haribhau,et.al.,2012)

Biochemical tests (Both Manual and automated method) and 16s rRNA analysis confirms that species of reference is of Genus Thermodesulfobacterium and species as commune. The evolutionary studies showed 80\% similarity index with Thermanaeromonas toyohensis.

The most important characteristic of this strain is high potential of sulphate reduction with negligible production of sulphide, thus there is no foul odour and even no precipitation of other metal present in the effluent (Z. Manafi, et.al.,2013). Considering all these aspects Thermodesulfobacterium commune (Accession Number KJ868727) will be an effective sulphate reducing thermophilic bacteria.

[1]. Christian Jeanthon,Ste!phane L'Haridon,Vale!rie Cueff,Amy Banta, Anna-Louise Reysenbach and Daniel Prieur, Thermodesulfobacterium hydrogeniphilum sp. nov., a thermophilic, chemolithoautotrophic, sulfate-reducing bacterium isolated from a deep-sea hydrothermal vent at Guaymas Basin, and emendation of the genus Thermodesulfobacterium, International Journal of Systematic and Evolutionary Microbiology (2002), 52, 765-772. 
[2]. Anna H. Kaksonen, Jason J. Plumb,Wendy J. Robertson, Stefan Spring, Peter Schumann, Peter D. Franzmann, And Jaakko A. Puhakka' Novel Thermophilic Sulfate-Reducing Bacteria From A Geothermally Active Underground Mine In Japan. Appl Environ Microbiol. , (2006)May; 72(5): 3759-3762.

[3]. Patil S. Z., Unnitha. A. R. and Unnikrishnan G., Biosulphidogenesis and Bioaccumulation of sulphate by moderately Thermophilic, Facultative anaerobic Bacteria Aeromonas hydrophila isolated from hot Water spring, Research Journal of Recent Sciences, (2014) Vol. 3(ISC-2013), 203-208.

[4]. Z. Manafi1, M. Hashemi1, H. Abdollahi,Gregory. J. Olson, Bio-corrosion of water pipeline by sulphate-reducing bacteria in a mining environment, Research Journal of Recent Sciences, November,( 2013) Vol. 12(46), pp. 6504-6516.

[5]. Carine Audiffrin, Jean-Luc Cayol, Catherine Joulian, Laurence Casalot, Pierre Thomas, Jean-Louis Garcia and Bernard Ollivier, Desulfonauticus submarinus gen. nov., sp. nov., a novel sulfate-reducing bacterium isolated from a deep-sea hydrothermal vent, International Journal Of Systematic And Evolutionary Microbiology, (2003) (5) 1585-1590.

[6]. Francis Amala Rejula and Masilamai Dhinakaran, Removal of Zinc (II) by Non Living Biomass of Agaricus Bisporus, Research Journal of Recent Sciences, September (2012),Vol. 1(9), 13-17.

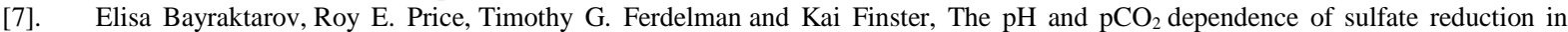
shallow-sea hydrothermal $\mathrm{CO}_{2}$ - venting sediments (Milos Island, Greece), Front. In Micro (2013)

[8]. Mehar Fatma, M. Iqbal R., Khan Asim Massod and nafees A. Khan, Coordinate changes in assimilatory Sulphate reduction are correlated to salt tolerance : Involvemetn of Phytohormones, Annual review and Research in biology, (2013),Vol.3(3)

[9]. Murhekar Gopalkrushna Haribhau ,Trace Metals Contamination of Surface Water Samples in and Around Akot City in Maharashtra, India, Research Journal of Recent Sciences, July (2012),Vol. 1(7), 5-9. 